\title{
Utopianism and Intentional Communities
}

Rbiannon Firth

in Matthew Adams and Carl Levy, Eds. (2018) Palgrave Handbook of Anarchism, Houndmills: Palgrave, pp. 491-510

\section{The Concept of Utopia}

'Utopia' is a neologism coined by Sir Thomas More in $1516^{1}$ based on a pun on the Greek eutopia meaning 'good place' and outopia meaning 'no place'. The concept is thus ambiguous and paradoxical: it implies positioning in time and space, yet also non-existence and elusiveness. Utopia has a particular resonance with anarchism, since it implies a lifeworld outside and beyond the usual terrain of politics, which celebrates the role of the imagination. Utopianism is an approach to social change that starts from the premise that there is something wrong with the world, and proceeds to dream and imagine how things might be if circumstances were radically changed. Utopias can take a variety of forms: the best known are fiction, social theory, and the topic of this chapter: experiments in alternative living. Utopianism poses a productive and creative tension between critique (of the status quo) and desire (for something different), whilst introducing an element of uncertainty, contingency and (im)possibility. ${ }^{3}$

This tension of (im)possibility - the good place we can desire and imagine, that nonetheless is no place - is the basis of a widespread sentiment of anti-utopianism throughout mainstream politics and culture, as well as many traditions of political theory. Criticisms of utopianism arise on two fronts. First, there are those who deny the possibility of any alternative to the current capitalist economy and neoliberal state politics. This stance is summed up in Francis Fukuyama's assertion that in liberal democracy we have reached 'the end of history'. ${ }^{4}$ Liberals such as Karl Popper have linked utopianism to totalitarianism since it is presumed to involve a strategy to be executed 'all at once' by 'a strong centralised leadership.' ${ }^{5}$ Popper's critique was specifically aimed at Marxism. For Popper, utopias were blueprints that were impervious to change, therefore oppressive of dissidents, whilst liberal society should aim for 'piecemeal' reformist and gradual change. Similarly, colloquial use of the term 'utopia' tends to associate it with perfection and impossibility. Examples of this understanding abound in popular culture, where societies designed on rational principles turn out to be terrifying dystopias in practice, for example in the films Demolition Man (1993), Brazil (1985), Blade Runner (1982), High Rise (2015), THX 1138 (1971) 
and others. Such films often centre on corrupt governments and renegade individuals who refuse to conform to stultifying norms. The underlying assumption is that since human beings are imperfect, and have different needs and desires, attempts to institute a singular vision of utopia from 'on high' would be totalitarian and oppress individuality. Of course, these kinds of misfired blueprints have nothing to do with anarchism: the implicit critique is usually aimed at Soviet Communism, an intensified and illiberal capitalism, or other dictatorial regimes. Nonetheless the cultural conflation of anarchism with violent utopianism strikes a misplaced fear in the hearts of many, whilst the conflation of utopias with totalitarianism silences and renders invisible true anarchist utopias. Thus, the conversational put-down familiar to many anarchists: it sounds great in theory, but it wouldn't work in practice'.

The second front from which the assault on utopianism is issued comes from within the field of radical theory. Whilst Marxists have tended to share with anarchists and utopians a critique of the current economic system and a revolutionary rather than reformist approach to change, Marx himself was critical of the utopian model of social change. His critique was directed at the 'utopian socialists' (who did not themselves use this term), Henri de Saint-Simon, Charles Fourier, and Robert Owen who lived in the early $19^{\text {th }}$ century. The utopian socialists drew up detailed plans of imaginary societies with the premise that if these were appealing and convincing then people of all classes would voluntarily join them. These idealistic plans were even put into place in communities such as Robert Owen's New Harmony and New Lanark and the Fourierist Brook Farm. ${ }^{6}$ Marx and Engels criticized the Utopian Socialists, because unlike their 'scientific' analysis of material conditions, the utopian socialists did not locate their alternatives within the context of existing class struggle, and therefore they were seen to lack an agent of social change. ${ }^{7}$

Marx and Popper define the field of utopianism differently: Popper's critique of utopianism was aimed at Marxists, whilst Marx believed the utopians were the utopian socialists and anarchists. Nonetheless, both classical Marxists and Liberals claim a unifying truth against which deviations are labelled 'utopian' and derided as impossible, when in fact, both of these modes of theorizing have their own utopian visions. Marx's utopian vision is future-oriented and descriptive; a communist society where one can 'hunt in the morning, fish in the afternoon, rear cattle in the evening, criticise after dinner'. ${ }^{8}$ Not too different then, from the utopias of the 'utopian socialists' perhaps, as well as the lives of many contemporary communards. It is uncontroversial, in contemporary societies contextualised by the collapse of the Soviet Union, to deride Marxist 
ideals as utopian, yet theorist Ruth Levitas asserts that 'we have to recognise that utopias are not the monopoly of the Left'. ${ }^{9}$ Contemporary conservative and neoliberal ideologies have their own utopian visions. Even though the conservative vision of the future is ostensibly based on preservation and restoration of hierarchies and inequalities: 'there is no doubt that there is an image of a desired society here, where there is unquestioned loyalty to the state (and where trade union activity is seen as a form of subversion), where there is hierarchy, deference, order, centralised power - and, incidentally, where the patriarchal family is the fundamental unit of society and where sexuality outside of this has been eliminated'. ${ }^{10}$ The neoliberal utopia portrays unbridled individualism, inexorable technological progress and unlimited natural resources, alongside 'the elimination of the public sphere, total liberation for corporations and skeletal social spending.'11 Anarchist utopias, which will be considered in more detail below, can be wildly variant but tend to be based on some vision of non-hierarchy, mutual aid, equal distribution, non-exploitative production and relationships, individual autonomy and freedom of expression. $^{12}$

Whether we perceive any of these variant visions as positive or negative, utopianism is the expression of diverse dreams of a better world, and has the potential to produce effects in the world by altering people's beliefs, values, emotions and actions. Rather than defining utopia in terms of form (e.g. fiction or social theory), or content (e.g. conservative or radical), many scholars of utopia agree that we should define utopia in terms of its function: 'the education of desire. ${ }^{13}$ Utopias and utopianism articulate critique and dissatisfaction (with either the entire status quo, or with specific elements within it) as well as desire, for something better. Whilst the forms and content of this expression of desire can vary wildly, we need not accept all forms of utopia as equally valid, and we may well share the Liberal fear of totalitarian and oppressive utopias as well as Marx's fear that utopias can be purely compensatory and removed from social struggle. Yet this does not necessitate that we give up on utopia entirely.

The issue at stake here is epistemological. Both the Liberal and Marxist visions have utopian elements, but they are obscured by the ways in which each lays claim to truth - whether this be in claiming to know the reality of 'human nature' or through having foundations in 'scientific analysis'. There are several problems here. First of all, the claim that some idea might be impossible to achieve in practice does not necessarily negate the possibility or desirability of trying, which might be a productive or ethically attractive process regardless. It is the truth- 
claiming, rather than the imaginative aspects of utopianism that anarchist anthropologist David Graeber argues lies at the heart of violence and oppression:

Stalinists and their ilk did not kill because they dreamed great dreams ... but because they mistook their dreams for scientific certainties ... In fact all forms of systemic violence are (amongst other things) assaults on the role of the imagination as a political principle. ${ }^{14}$

It is not, then, the lack of a basis in 'truth' which makes particular utopias potentially oppressive. Rather, the harm resides in the totalising effects of utopias which lay claim to singular and unassailable truth, through abstract rationalism, pragmatism, or scientism. The utopias of the mainstream have often been as hierarchical and authoritarian as the cultures which produced them. ${ }^{15}$ As the theorist of utopianism, Susan McManus puts it, 'ostensibly authoritative modes of knowledge production, are always-already creative epistemologies ... that efface their contingency and creative power in favour of their legislative and authoritative power. ${ }^{16}$

Other ways of thinking and doing utopia are possible. Tom Moylan and Lucy Sargisson identify trends within utopian fiction, which they term 'critical' ${ }^{17}$ and 'transgressive'. ${ }^{18}$ In these literary works, such as Marge Piercy's Woman on the Edge of Time, Joanna Russ' The Female Man and Samuel R. Delany's Triton, the critical and creative function of utopia is not obscured behind truth-claims. The societies portrayed do not appear as perfect visions, nor as closed blueprints. The authors take great trouble to explore and celebrate themes of difference, deviance and dissent. Many of these creative and playful fictional utopias have explored anarchist themes, for example Ursula LeGuin's The Disposessed, Starhawk's The Fifth Sacred Thing and Charlotte Perkins Gilman's Herland. Such utopias are 'critical', Moylan argues, in three ways: they are critical of the status quo; they are also self-critical, exploring forms of domination and exclusion that arise from within; and they are critical in their aim to produce social change through a critical mass; a flourishing of libertarian utopias in all their diverse forms. ${ }^{19}$

Thinking about the utopian impulse as both a means of expressing and educating desire can help us to realise that utopia is not always about the future, nor about impossible blueprints, but rather it is something endemic to the present of everyday life. Theorists such as Ernst Bloch have interpreted practices as diverse as medicine, fairy tales and architecture as utopian. ${ }^{20}$ Thus, whilst utopias and utopianism are not necessarily anarchist, there is a peculiar resonance between 
this playful, contingent and experimental function and anarchism, and utopianism has played an important role in the history of anarchism. ${ }^{21}$ Similarly, anarchism has often been associated with the impossible and the perilously idealistic, yet seeds of anarchist utopias can be found all around us in everyday life..$^{22}$ Literary critical utopias offer us a useful way in to thinking about the political function of lived utopias, because they offer a vision of social change that does not separate means from ends; a way to educate desire by experimenting with new ways of living in the here-and-now. Such utopias are both possible and pragmatic, whilst engaging concretely in social struggle. I will now turn to a consideration of lived and applied aspects of utopianism as they relate to anarchism.

The relationship between anarchism and utopia: Why anarchists should be interested in intentional communities.

Literary 'critical utopias' such as those mentioned above have a resonance with anarchism. They help us to criticise dominant social and political arrangements, imagine alternatives, transgress our previously unquestioned beliefs, and in so doing, transform consciousness and 'educate desire' towards a more liberatory way of life. However there is no denying that reading is usually a rather solitary activity, and does not in itself change the world. Utopias in the form of lived collective experiments are also possible. The idea of voluntary communities based on shared values and principles as forms of social change have been important to anarchist theorists such as Max Stirner, who spoke of a 'union of egoists'; ${ }^{23}$ Gustav Landauer whose 'social anarchism' was based on a 'union of individuals' who voluntarily founded and joined small socialist communities, ${ }^{24}$ and Martin Buber, who postulated that small communities facilitate 'a renewal of society through its cell tissue'. ${ }^{25}$ This was based on the premise that the state is not a 'thing' that can be identified and destroyed in one fell swoop, through revolution, but rather is a particular form of dominatory relationship between people, ${ }^{26}$ or to Stirner, something more akin to an alienated internal psychological state; a system of beliefs and values that he termed a 'spook'. ${ }^{27}$ These insidious beliefs and relationships create the conditions for agents of the state to act as such, for subjects and subordinates to defer to their authority, and thus for the logic of 'the state' to continue. The state is theorised as a powerful and dangerous fiction which is perpetrated through claims to, and beliefs in, its truth. Buber argued that Marx shared the same goal as utopian socialists and anarchists, yet the belief that this goal could be achieved through a topdown hierarchical revolution was mistaken. For Buber, domination could not be overcome by means of further domination. Rather, the best way to overcome the state is through 
experimentation and practice, or to use a frequently used adage in prefigurative movements: 'be the change you want to see. ${ }^{28}$

Many anarchist theorists have studied existing practices through the framework of anarchism, even where those practices were not anarchist by intent, for example, Peter Kropotkin's descriptions of mutual aid in primitive and medieval societies ${ }^{29}$ and Colin Ward's descriptions of anarchy in everyday life. ${ }^{30}$ Taking an ethnographic approach to studying existing examples of anarchy in action should not simply serve the purpose of 'proving' anarchist theory to be possible or correct. Intentional communities are invaluable for anarchists, because studying already-existing 'utopias' can provide inspiration for further anarchist practices whilst helping to explore problems and tensions that arise in practice. Graeber calls this process 'utopian extrapolation': 'a matter of teasing out the tacit logic or principles underlying certain forms of radical practice, and then, not only offering the analysis back to those communities, but using them to formulate new visions. ${ }^{31}$

\section{Intentional Communities as practical utopias}

Intentional communities can be defined as:

A group of five or more adults and their children, if any, who come from more than one nuclear family and who have chosen to live together to enhance their shared values or for some other mutually agreed-upon purpose. ${ }^{32}$

The history of intentional communities is rich and varied, spanning centuries and continents, and can be traced back to the $6^{\text {th }}$ Century BCE in what is now Southern Italy, where Pythagoras founded the community Homakoeion, based on vegetarianism, spirituality and equality of the sexes. Around the same time, followers of Buddha joined together to form ashrams to work and live together in a spiritual manner. ${ }^{33}$ Notable movements in the history of intentional communities include the Diggers of seventeenth century England, a group of Protestant radicals seen as antecedents of modern anarchism, who took their name from their attempts to farm common land. ${ }^{34}$ The utopian socialists of the nineteenth century (discussed above) also deserve a mention in this brief history, as well as the counter-cultural movements of the 1960s and 1970s, which led to the foundation of several thousand communes throughout the Western world. ${ }^{35}$ Many of these were short lived, but a small number continue to this day. That nobody has 
written a comprehensive history representative of the diversity of the movement worldwide attests to the magnitude of such a task. The diversity and scope of intentional communities are explored in texts such as Chris Coates' Utopia Britannica ${ }^{36}$ for a history of utopian experiments in Britain between 1325-1945; the edited book West of Eden ${ }^{37}$ for a history of intentional communities in North California focusing on the 1960s-70s, or James Horrox' A Living Revolution for a history of anarchism in the kibbutz movement of Israel. ${ }^{38}$ The examples drawn on in this chapter are mostly based in the United Kingdom ${ }^{39}$, and more information on the UK intentional communities movement can be found at the Diggers and Dreamers website. ${ }^{40}$ Further information and a directory of the worldwide intentional communities movement can be found on the website of the Fellowship for Intentional Community. ${ }^{41}$

Intentional communities can include shared households, cohousing communities, ecovillages, communes, survivalist retreats, kibbutzim, ashrams, housing cooperatives, squats. They can be urban or rural. The kinds of shared principles that they are based on, similarly to fictional and political utopias, are wildly variant and can include political, religious, social or spiritual values and practices, and the principles can be as vague as 'commitment to a shared lifestyle' or 'commitment to shared living ${ }^{42}$. Most, but not all intentional communities have a constitution or founding document which sets out shared principles, which may or may not be open to negotiation and modification by new members. The question of utopian intent is complex and has been the subject of debate ${ }^{43}$. Not all intentional communities are anarchist, though some are explicitly inspired by anarchist principles, such as Brambles in Sheffield, UK. ${ }^{44}$ Most embrace equality and non-hierarchy, yet some have been strictly ordered and hierarchical ${ }^{45}$ whilst others prioritise religious or spiritual aims. Some communities, such as Findhorn community in Scotland ${ }^{46}$ and The Catholic Worker Farm in Hertfordshire ${ }^{47}$ aim to illustrate continuity between spirituality and social justice. Communities therefore vary wildly in the values and forms of organisation they embrace, and some of these, explicitly or not, are more resonant with anarchist theory than others. Of particular relevance for our purpose here are communities that espose critique of hierarchy as core values and aim to practice non-hierarchy in their organization and decision-making. Intentional communities have frequently been studied as utopian experiments and in the context of the utopian studies canon ${ }^{48}$. However, few communards define their practices as utopian, perhaps due to an association of the colloquial understanding of utopia as both 'perfect' and 'impossible'. Intentional communities are neither perfect nor impossible. Nonetheless, framing their activities as utopian can help us to understand something about them, whilst intentional communities also have much to tell us about anarchism. 


\section{Property Relations}

One of the ways in which intentional communities bring anarchist ideals into practice is through experimenting with different forms of property relations. The idea that 'property is theft' was most famously captured by Pierre-Joseph Proudhon, ${ }^{49}$ yet opposition to both state and capitalism unites all anarchists. Anarchists view property as a source of coercive authority and tend to favour economies based on mutual aid, ${ }^{50}$ gift economies ${ }^{51}$ and ideas of the commons. ${ }^{52}$ Intentional communities challenge dominant property narratives that inform modern attitudes, beliefs and behaviour about property. ${ }^{53}$

Ownership is a complex issue for intentional communities, because whilst they attempt to actualise alternative property relations, like other anarchist practices they have to exist within a capitalist economy and must assume modes of ownership within or against this. In the United Kingdom, communities experimenting with alternative living, like anyone looking to inhabit a space, by necessity assume one of four different practical models of ownership of their space: squatting, renting, fully mutual housing co-operatives and private ownership (with or without a mortgage). Whilst squatting offers arguably the most integrated critique and resistance to capitalist models of ownership, it tends to be a precarious and temporary practice and offers less opportunity for sustained and long-term experiments with utopian social relations. Autonomous social centres sometimes use squatting and renting, but intentional communities, which often aim for stability and longevity, tend to favour the fully mutual housing co-operative model. Fully mutual ownership requires a community to own a place either outright or with a mortgage. It is a legal model whereby members pay a small fee, usually the legal minimum of $£ 1$ in order to become a shareholder, whereby they become both landlord and tenant, and are granted occupancy subject to the particular rules of the community. Within this legal model, communities have evolved richly diverse cultures of co-operative living and alternative property relations. If there is a mortgage to be paid, usually members pay 'cost-share', a monthly payment similar to rent, which will often include shared goods such as food, cleaning products, council tax, maintenance and other expenditures. All members are involved in decisions around costshare, usually through consensus. There is often an expectation that members will spend a certain amount of time working for the co-operative, outside of which members are entitled to earn what they like through other jobs. Exceptions exist, such as Findhorn Community, where core members are employed full-time by the community. A very small number of communities 
engage in income sharing, which was popular during the 1960s-70s wave of co-operatives but has fallen out of fashion. ${ }^{54}$ Income sharing involves surrendering one's personal income to the community which is then distributed amongst members according to agreed procedures. Although this practice is not widespread, most communities have an ethos of sharing nonmonetary goods and prioritizing the good of community over personal gain. This has deep implications for subject-formation, and Sargisson argues that such practices 'transgress and disrupt the egoistic self of possessive individualism. ${ }^{55}$ Utopian practices in intentional communities disrupt the ontological foundations of widely held beliefs in the naturalness and necessity of neoliberal capitalism, illustrating that another world is possible. This highlights a key function of utopianism: not only do utopias offer critique, but they are spaces in which we can think and do things differently.

\section{Decision-Making}

A key tenet of the anarchist tradition is rejection of political representation: the idea that one person can represent others, meaning alienation of choice, expression, action and decisionmaking which occurs when political actors speak, campaign, act and decide on behalf of others in the political arena. Bakunin criticised representative democracy when it was just an embryonic movement. Seen by many as a force for liberation, Bakunin termed it 'bourgeois democracy"56 and 'so-called representative democracy'. ${ }^{57} \mathrm{He}$ argued it was an expression of existent relations of inequality, whereby a political elite with privileged access to resources such as wealth, education and free time are able to deceive people into thinking it is acting in their interests whereas it is 'invariably exploiting them'. ${ }^{58}$ Max Stirner argued that not only political representation, but any form of subjugation to ideas and principles that are not one's own leads to oppression of minorities and self-creativity. ${ }^{59}$ More recently, Todd May ${ }^{60}$ and Saul Newman ${ }^{61}$ have drawn an anarchist critique of representation from post-structural theorists such as Derrida, Deleuze and Guattari and Foucault. The anarchist critique seems to have gained increasing importance during a time that some academic commentators label a 'crisis of representation' whereby many publics, not only anarchists, are losing faith in the ability of representative democracy to articulate their interests. ${ }^{6263}$ The anarchist alternative to 'representative democracy' is sometimes called 'direct democracy' although some anarchists eschew the term 'democracy' altogether, since it means 'rule by the people', and 'the people' is an abstraction. ${ }^{64}$ 
A specific practice associated with anarchism, which attempts to offer an alternative to representation, is consensus decision-making. Consensus in its most basic form means that all people affected by a decision can take part in deciding, in a face-to-face process, and everyone must agree before action is taken. It means that minorities have power to veto and so cannot be ignored. Consensus requires commitment to making decisions acceptable to everyone affected by the outcome. Instead of choosing between polarised positions through voting, consensus involves creatively modifying options through sometimes long processes of negotiation in order to take everyone's needs into account. ${ }^{65}$ Unlike political representation, consensus does not assume unity of identity or desires that can be represented as a single vision. Rather, consensus assumes conflict -minorities can veto a decision, so they cannot be ignored. Combining perspectives on an issue in both process and outcomes can lead to more creative and effective decisions, and the process itself helps to build bonds and community. Consensus requires trust and openness, unlike conflict and competition at the basis of parliamentary democracy. All participants invest time and energy in the process and all agree so they are more committed to implementing the outcome. ${ }^{66}$

Many intentional communities, whether explicitly anarchist or not, prefer to use consensus for making important decisions. Practical details vary from group to group. Usually there is a facilitator, whose role is to make sure everyone has equal opportunity to speak and procedures are followed. Some groups have informal procedures, simply discussing a subject until everyone agrees. Other communities use coloured cards or hand signals, coded to communicate agreement, disagreement (blocking a decision), and desire to intervene with a question or comment. The purpose of such systems is to minimise talking-over and interrupting. When well facilitated, consensus should allow everyone to speak, be listened to and understood, whilst louder voices and more assertive personalities should be prevented from dominating the proceedings. Some groups have a pre-consensus 'heart session' where participants can talk about, for example, how their week has been and reveal any personal worries or troubles, with the premise that this might ameliorate the possibility of repressed emotions being played out during the consensus process. ${ }^{67}$

Consensus requires small groups to work effectively. Communities visited during my research varied from 4 members to about 400. As group size increased, consensus became increasingly difficult, and larger communities tended to delegate to sub-groups where possible but use 
varying forms of majority voting or representation for decisions affecting the entire community. ${ }^{68}$ Critics of anarchism cite this as a reason that anarchism could not work on a largescale. ${ }^{69}$ However, this misunderstands the anarchist position, which resides precisely in a rescaling and dis-alienation of society. ${ }^{70}$

\section{Scale and Federation}

A further resonance between the intentional communities movement and anarchism resides in the idea and practice of networked federation. The best-known anarchist proponent of federalism was Proudhon. ${ }^{71}$ Many other anarchists have based visions on the idea of small and diverse self-governing communities associated through networks and loose associations, forming non-coercive organizations to communicate. ${ }^{72}$ Federation is a partial response to the issue of scale. Many aspects of anarchism, for example, decentralised production, affinity, community and limits on authority require communities not to expand over a certain size. Federation in anarchism means that 'the basic idea is to reproduce the collective, not expand it'. ${ }^{73}$ The principle of small-scale communities is also espoused by eco-anarchists such as Leopold $\mathrm{Kohr}^{74}$ who anticipated the deep-ecology movement's ${ }^{75}$ preoccupation with bioregions and decentralisation through his promotion of 'human scale' and small communal life. The issue of size and scale is also important in utopian studies. John P. Clark argues that the dominant utopia is based on a fantasy of infinite superpower that 'drives relentlessly toward the destruction of all diversity and complexity $^{76}$ in the name of progress, whilst anarchist utopias are experimental and connect the rich specificity of 'sense of place' with diverse cultures and ecosystems. ${ }^{77}$ Tom Moylan also argues that whilst top-down, totalitarian utopias assume a singular jurisdiction over a very large area, critical utopianism assumes a proliferation of diverse small-scale experiments, calling for an 'alliance of margins without a centre ${ }^{, 78}$.

Many intentional communities practice federation through the organization Radical Routes. Radical Routes is 'a network of radical co-ops whose members are committed to working for positive social change. ${ }^{79}$ Four times a year, nominated members will attend a gathering at which issues affecting co-operatives will be discussed, such as national laws and policies, and new applications to join, as well as issues facing groups in financial need (Radical Routes can provide loans). The organization's purpose is to provide 'a form of structured mutual aid' that is 'about people taking control of their own housing, work, education and leisure activities' ${ }^{80}$ In a very real 
and practical sense, intentional communities, networked through Radical Routes, are engaged in renewing society from the grassroots, here-and-now, as called for by anarchists like Buber and Landauer. Nonetheless, there are several controversies and tensions. Debates issue from anarchist theory about communal life and from within the communal movement.

\section{Controversies and tensions.}

\section{'lifestyle anarchism' vs 'social anarchism'}

A key controversy about communities within anarchist theory is somewhat reflective of erstwhile tensions between Marx and the Utopian Socialists. Murray Bookchin ${ }^{81}$ claims to discover two trends within contemporary anarchism: 'Lifestyle anarchism' and 'social anarchism'. 'Lifestyle anarchism', according to Bookchin, is individualistic, bourgeois and immature. It is associated with thinkers such as Max Stirner, Emma Goldman, Hakim Bey and John Zerzan, and practices such as drug-taking, counter-culture, and celebrating the imagination, ${ }^{82} \mathrm{New}$ Age spirituality and critique of technology and science. ${ }^{83}$ Bookchin argues that it is divorced from social struggle and the working classes. ${ }^{84}$ 'Lifestyle anarchists' demand to live anarchy in the present, divorced from struggle or revolution, demanding social change through lifestyle changes. Many of these descriptors would fit intentional communities. Bookchin counterposes this to 'social anarchism', which beseeches people 'to rise in revolution and seek the reconstruction of society' ${ }^{85}$ with an emphasis on mutual responsibility, collectivism, enlightenment rationality, and institutional structures. ${ }^{86}$

Bookchin has been critiqued by post-left anarchist Bob Black, whose book Anarchy after Leftism ${ }^{87}$ concentrates on debunking Bookchin. Black argues that Bookchin is a communist in disguise, rehashing tired Marxist arguments about the need for top-down social change. Bookchin accuses anarchists of hedonism, yet Black argues that anarchism has always been about building the future anarchists want to see in the present. ${ }^{88}$ Whilst Bookchin calls 'lifestyle anarchism' individualistic, Black argues this is a straw-man concept designed to obfuscate the fact that Bookchin is attempting to construct a top-down, rather than anarchist utopia - he wants to institute his own idea of the good life. Black proposes the rejection of political tendencies associated with leftism, particularly: vanguardism; mass politics; identity politics; representation; work; and activism based on guilt, responsibility and repression of desire. ${ }^{89}$ Instead, post-left anarchism favours 'the immediate expression of desire, constructing the kind of world one wants 
to live in immanently and horizontally, and radically and antagonistically rejecting or attacking the social forms and institutions of the dominant system,90.

In practice, many intentional communities fall somewhere in the middle or outside of this theoretical debate. Whilst they do often have a preeminent concern with lifestyle choices and "politicising the quotidian" ${ }^{91}$, this does not mean they always express their desires immediately, live intensely or antagonistically reject dominant social forms in the way described by post-left theory. The intentional communities movement has been argued to espouse middle-class values ${ }^{92}$ ${ }^{93}$, yet may have more class diversity than often presumed. ${ }^{94}$ Many communities are very much involved in wider social and political struggles. For example, one community gives up part of its space for a refugee shelter, and does a lot of work in refugee advocacy, whilst others open their communities for school trips around food and environmental sustainability and justice. Individual members dedicate huge amounts of time to education, political protest, direct action, radical publishing and many other actions.

\section{Commitment vs temporariness}

Usually, intentional communities require a high degree of commitment in order to produce social cohesion and stability. ${ }^{95}$ Many communities have long joining procedures for this reason. ${ }^{96}$ For example, Mornington Grove community in Bow, East London, outlines a nine-stage joining procedure on its website, which it states takes at least six months. They state the reason: 'we aim to be a relatively stable community, and it takes time and energy to join and get to know the ropes, we ask all new members to make a commitment to stay for two years. ${ }^{97}$ However, Hakim Bey, a post-left anarchist, argues in his book Temporary Autonomous Zone ${ }^{98}$ that anarchist communities, which he terms 'intentional communities' and 'pirate utopias', ${ }^{99}$ ought to be shortlived and exceptional, in order to preserve levels of intensity required for radicalism, and to prevent ossification into fixed structures and stable hierarchies: 'Like festivals, uprisings cannot happen every day — otherwise they would not be 'nonordinary.' But such moments of intensity give shape and meaning to the entirety of a life ${ }^{, 100}$. Conversely, Stephven Shukaitis has argued it is precisely this embedding of anarchist principles into 'ordinary' everyday life that constitutes their value and the sustainable 'social reproduction' of anarchist ways of living. ${ }^{101}$ This involves activities like caring for the young and elderly, which tend to require some degree of communal stability and longevity. Furthermore, Shukaitis argues it is very much the case that struggles 
around the everyday and 'ordinary' can connect 'minor moments of rupture and rebellion into connected networks of struggle. ${ }^{102}$ Of course, it is quite possible that both these modes of resistance are important, for example communities in squats tend to be more temporary, yet more radical in their ability to highlight and resist exploitative property relations, whilst also better suited for people in precarious circumstances. Whilst some degree of stability is important for many communards, it is likely Kanter overstates the case by defining the 'success' or 'failure' of an intentional community in terms of its longevity, since even short-lived communities can be intensely meaningful to those who participated.

\section{'Tyranny of structurelessness' vs 'tyranny of tyranny'}

The term 'tyranny of structurelessness' is drawn from an article by Jo Freeman, which is widely cited as an idea, sometimes even by people who are not aware of the text, in activist circles including intentional communities. Freeman's analysis, written from within the 1970s feminist movement, revolves around the idea that informal groups without clear organisational structures are susceptible to power struggles and undemocratic hierarchies. She argues that a lack of formal structure encourages 'unquestioned hegemony' ${ }^{103}$ since it leads to the formation of elites, where cliques of friends dominate groups, and encourages a '"Star" system' where charismatic members are perceived to be representatives without undergoing democratic election ${ }^{104}$. Her final criticism is that informal groups are not politically effective, and are only useful for a 'consciousnessraising' phase, rather than for achieving real change. ${ }^{105}$ She proceeds to outline seven recommendations for 'democratic structuring', including: delegation of authority for specific tasks by democratic procedures; requiring those in authority to be responsible to those who selected them; distribution of authority among 'as many people as is reasonably possible'; rotation of tasks; allocation of tasks along rational criteria; frequent diffusion of information; and equal access to resources (Freeman 1984[1972]: 14-15). ${ }^{106}$

In reply to this essay, Cathy Levine argues from an anarchist perspective that small, structureless groups are not ineffective and unintentionally oppressive, but rather 'a valid, conscious strategy for building a revolutionary movement' and are in fact less tyrannical than the organized democratic groups Freeman recommends. ${ }^{107}$ The anarchist ideal of 'small groups in voluntary organization ${ }^{108}$ is the antidote to mass hierarchical organisations with centralised control - such as capitalist, imperialist states - but also, Levine argues, traditionally patriarchal Left party politics. 
For Levine, consciousness-raising is the very core of political movement, which should not concentrate on a power takeover, but rather become a matter of building a women's culture from the bottom-up.

This debate has a lot of relevance and reflects debates within intentional communities. Many, if not all, communities encounter issues whereby some individuals dominate certain situations, and unintentional hierarchies arise, often based on gender, education, longevity (in the group) and confidence. ${ }^{109}$ This of course takes place everywhere in everyday life, yet arguably there is more reflexivity in intentional communities, who tend to discuss these matters. Furthermore, intentional communities do tend already to adopt many of Freeman's principles, for example, it is impractical to bring all decisions to meetings, so there is delegation to sub-collectives (for example, there may be a sub-collective for permaculture gardening and another for buildings maintenance). Groups also have formal organizational procedures laid out in constitutional documents. This ought not to be taken as straightforward vindication of Freeman against Levine's more anarchist line of thought. Jason McQuinn has claimed: 'each of [Freeman's] suggestions are far more commonly accomplished by informal libertarian groups than by any ... of the formal organizations of the world, including formal anarchist organizations. And they can be recommended for any organization, whether it's formal or informal. ${ }^{110}$ Thus Freeman's principles are already anarchist principles, except, McQuinn argues, her two suggestions that are 'explicitly based on authoritarian assumptions'; ${ }^{111}$ those are: 'distribution of authority among as many people as is reasonably possible' and 'requiring those in authority to be responsible to those who selected them, ${ }^{112}$ which simply describe the very kinds of representative democracy and political authority that anarchists are against. Similarly to anarchists, intentional communities tend to reject political authority and representation, and in the preceding sections I have attempted to read anarchism in and through the organizational processes of intentional communities. However, this approach does raise some issues, which will be addressed in the conclusion.

\section{Conclusion: What do utopian and intentional communities reveal about anarchism as an ideology?}


Intentional communities vary drastically in how they are organized, the ideals and values they follow, whether they are urban or rural, the ways in which they arrange and occupy space, and their relationships to ownership, property and production. There is no single model, and not all intentional communities are anarchist, nor even broadly libertarian or leftist. Nonetheless, there are many utopian threads that weave through intentional communities and anarchism. The histories of both movements are tied together through the ideas and practices of utopian socialists, theorists, hippies, feminists and a host of other characters seeking a better way of living. Throughout this history, anarchists, utopians and communards have been subject to the same invalidating criticisms: that their values are idealistic and their very real, embodied practices and experiences are 'impossible'. At the same time anarchists and utopian communards have shared a positive vision: of grassroots, bottom-up social change, which starts in the here-andnow, transforming relationships and consciousness, rather than being deferred to the future, which takes the form of continually evolving experiments rather than totalitarian blue-prints. Small groups, face-to-face relationships, and dis-alienated relations with nature are the bedrock of many anarchist utopias, and intentional communities bring these into practice.

Utopianism as a methodology operates through critique and transgression, which has a consciousness-raising function. Both anarchism and intentional communities arise from a context where certain assumptions are taken-for-granted: that a key purpose of the state is to protect (unequal) property relations; effective decisions can only be made when political authority is delegated to a representative; and the essential territorial scale of a political entity is the nation state. The nation state is often taken to be a natural or inevitable political entity rather than something that is itself politically constructed ${ }^{113}$, and the necessity of a state with a monopoly on the use of violence to protect private property rests on essential claims about 'human nature' which are actually contestible. These truth claims - about what it is to be human, and to belong, obfuscate political desires and interests behind truth-claiming discourse. Intentional communities posit alternatives: gift-economies, face-to-face relationships and consensus decisions in small, loosely federated groups. In so doing, they de-naturalise taken-forgranted assumptions about human nature, economy and belonging. This is a self-avowedly utopian approach, which attempts to embrace and harmonise different desires, and take everyone's needs and interests into account. The approach is one of voluntarism and experimentalism: many flowers may bloom with no single over-arching approach to either epistemology or politics of community. 
Anarchism fits quite well as an epistemological approach to understanding such communities, but utopianism and the intentional communities movement are much broader than anarchism. The relationship is perhaps best thought of as rhizomic, rather than foundational or definitional. To restrict one's analysis to communities that explicitly named themselves anarchist would leave a very small number of cases. Therefore, when working with intentional communities one frequently finds oneself interpreting practices as anarchist that practitioners might not self-define as such. This can be a useful exercise, as intentional communities have much to offer anarchism, and vice versa. Nonetheless, we must be careful not to 'colonise' practices and practitioner perspectives by representing them only using ideals and terminology that are not their own. Furthermore, one risks compromising anarchist values by reading certain practices uncritically as anarchism, when in fact they might fall short. Many community members have carefully considered personal perspectives, frequently inspired by, reacting to, and in dialogue with their encounters with anarchism and anarchists through their communities and other radical networks. Perhaps the most important lesson to be drawn from the intentional communities movement are the possibilities for connection and affinity between our wider anarchist movements and intentional communities, as well as the possibility of taking inspiration from intentional communities for practices we can bring to our own unintentional communities, classrooms, neighbourhoods and relationships.

\footnotetext{
${ }^{1}$ T. More, Utopia, (London: Penguin Classics, 2004 [1516]).

${ }^{2}$ K. Taylor, 'Utopianism', in I. McLean and A. McMillan (Eds.) Oxford Concise Dictionary of Politics (Oxford: Oxford University Press, 2003), pp. 554-6 (p. 554).

${ }^{3}$ B. Davies, 'The (im)possibility of intellectual work in neoliberal regimes', Discourse: Studies in the cultural politics of education, 26.1(2005), pp. 1-14. “(Im)possibility” refers the possibility, embedded in the impossible, which has potential to disrupt the dominant order in the mind of a people, sometimes violently.

${ }^{4}$ F. Fukuyama, The End of History and the Last Man (New York: Free Press, 1992).

${ }^{5}$ K. Popper, The Open Society and its Enemies (Volume I) (London and New York: Routledge, 2002 [1945]), p. 173.

${ }^{6}$ M.L. Berneri, Journey Through Utopia (New York: Schocken Books, 1982[1950]), pp. 207-219.

${ }^{7}$ K. Marx and F. Engels, The German Ideology (New York: Prometheus Books 1998[1846]), p. 26.

${ }^{8}$ Marx and Engels, ibid, p. 53.
} 
${ }^{9}$ R. Levitas, The Concept of Utopia (New York: Syracuse University Press, 1990), p. 184.

${ }^{10}$ Levitas, ibid, p. 180.

${ }^{11}$ N. Klein, The Shock Doctrine (London: Penguin, 2007), p. 15.

${ }^{12}$ L. Davis, 'Introduction', in L. Davis and R. Kinna (Eds.), Anarchism and Utopianism (Manchester: Manchester University Press, 2009), pp. 1-5.

${ }^{13}$ E.P. Thompson, William Morris: Romantic to Revolutionary (London: Merlin Press, 1977[1955]), p. 791.

${ }^{14}$ D. Graeber, Fragments of an Anarchist Anthropology (Chicago: Prickly Press, 2004), pp. 10-11.

${ }^{15}$ P. Marshall, 'Preface' in L. Davis and R. Kinna (Eds.), Anarchism and Utopianism (Manchester: Manchester University Press, 2009), pp. xiii-xvi, p. xiv.

${ }^{16}$ S. McManus, Fictive Theories: Towards a Deconstructive and Utopian Political Imagination, New York: Palgrave Macmillan, 2995), p. 1.

${ }^{17}$ T. Moylan, Demand the Impossible: Science fiction and the Utopian Imagination (New York: Methuen, 1986).

${ }^{18}$ L. Sargisson, Contemporary Feminist Utopianism (London: Routledge 1996).

${ }^{19}$ Moylan, op. cit., Ref. 17, p. 10.

${ }^{20}$ E. Bloch, The Principle of Hope (Volumes 1-3), trans. N. Plaice, S. Plaice and P. Knight (Cambridge MA: The MIT Press 1986 [1959]).

${ }^{21}$ J. P. Clark, 'Anarchy and the dialectic of utopia' in L. Davis and R. Kinna (Eds.), Anarchism and Utopianism (Manchester: Manchester University Press, 2009), pp. 9-29.

${ }^{22}$ C. Ward, Anarchy in Action (London: Allen and Unwin, 1973).

${ }^{23}$ M. Stirner, The Ego and Its Own (London: Rebel Press, 1993 [1844]), p. 308.

${ }^{24}$ G. Landauer, For Socialism, trans. D. J. Parent (St Louis: Telos Press, 1983 [1911]).

${ }^{25}$ M. Buber, Paths in Utopia (New York: Syracuse University Press 1996 [1949]), p. vii

${ }^{26}$ Landauer, op. cit. Ref. 24, p. 141.

${ }^{27}$ Stirner, op. cit., Ref. 23, p. 39.

${ }^{28}$ J. Pickerill and P. Chatterton, 'Notes Towards Autonomous Geographies: Creation, resistance and self-management as survival tactics', Progress in Human Geography, 30/6 (2006), pp. 730-746; p. 738. It is worth noting that this phrase is often falsely attributed to Ghandi, but actually represents a simplification of his thoughts on the matter. For further discussion on this, see B, Morton, 'Falser Words Were Never Spoken', The New York Times (August 29 2011) Available at: http://www.nytimes.com/2011/08/30/opinion/falser-words-were-never-spoken.html, accessed 10.03.2017.

${ }^{29}$ P. Kropotkin, Mutual Aid: A Factor of Evolution (London: Freedom Press 2009[1902]). 
${ }^{30}$ Ward, Anarchy in Action, op. cit. Ref. 22.

${ }^{31}$ D. Graeber, 'The Twilight of Vanguardism', in Possibilities: Essays on hierarchy, rebellion and desire (Oakland: AK Press, 2007), pp. 301-312, p. 310

${ }^{32}$ L.T. Sargent, 'The Three Faces of Utopianism Revisited', Utopian Studies, 5.1 (1994), pp.1-37.

${ }^{33}$ L. Kelley, 'Timeline of Intentional Communities', Peace News, 2446 (2002), available at: http://peacenews.info/node/3538/timeline-intentional-communities, accessed 5.05.2016.

${ }^{34}$ Berneri, op. cit. Ref 6, pp. 146-150.

${ }^{35}$ A. Rigby, Alternative realities: A study of communes and their members (London: Routledge \& Kegan Paul, 1974).

${ }^{36}$ C. Coates, Utopia Britannica: British Utopian Experiments 1325 - 1945. Vol. 1 (London: Diggers and Dreamers Publications, 2001).

${ }^{37}$ I. Boal, J. Stone, M. Watts, and C. Wonslow (Eds.) West of Eden: communes and utopia in northern California (Oakland: PM press, 2012).

${ }^{38}$ J. Horrox, A Living Revolution: Anarchism in the Kibbutz, Movement (Edinburgh: AK Press, 2009).

${ }^{39} \mathrm{My}$ own interest and knowledge arises from my doctoral research on utopian intentional communities in the UK, which involved ethnographic research with ten different intentional communities in the summer of 2007. This was published as: R. Firth, Utopian Politics: Citizenship and Practice (London: Routledge 2012).

${ }^{40}$ Diggers and Dreamers, http://www.diggersanddreamers.org.uk/, accessed 10.03.2017.

${ }^{41}$ Fellowship for Intentional Community, http://www.ic.org/, accessed 10.03.2017.

${ }^{42}$ Examples of constitutional documents of intentional communities can be found on the web-pages of individual communities, for example Findhorn Common Ground (n.d.) available at:

https://www.findhorn.org/wp/wp-content/uploads/2013/06/CommonGround2012.pdf , accessed 10.03.2017.

${ }^{43}$ L. Garforth and P. Kraftl (Eds.) Special issue: Utopia and Intention, Journal for Cultural Research, 13.1 (2009).

${ }^{44}$ Brambles Housing Co-operative, https://sheffield.coop/wiki/Brambles, accessed 10.03.2017.

${ }^{45}$ B. Shenker, Intentional Communities: Ideology and Alienation in Communal Societies (London: Routledge and Kegan Paul, 1986).

${ }^{46}$ Findhorn Foundation Community, https://www.findhorn.org, accessed 10.03.2017.

${ }^{47}$ Catholic Worker Farm, http://www.thecatholicworkerfarm.org/, accessed 10.03.2017.

${ }^{48}$ Firth, Utopian Politics, op. cit., Ref. 41; E. Webber, Escape to Utopia: The Communal Movement in America (New York: Hastings House 1959); R.M. Kanter, Commitment and Community: Communes and Utopias in Sociological Perspective (Cambridge, MA: Harvard University Press, 1972); P. Abrams and A.W. McCulloch, Communes, Sociology and Society (Cambridge: Cambridge University Press 1976); L. Veysey, The Communal Experience: 
Anarchist and Mystical Communities in Twentieth-century America (Chicago: University of Chicago Press 1978); D. Pepper, Communes and the Green Vision: Counterculture, Lifestyle and the New Age (London: Green Print 1991); L. Sargisson, Utopian Bodies and the Politics of Transgression (London: Routledge, 2000); L. Sargisson, and L.T. Sargent, Living in Utopia: New Zealand's Intentional Communities, (Aldershot: Ashgate, 2004).

${ }^{49}$ P-J. Proudhon, What is Property? (Cambridge: Cambridge University Press, 1994[1840]).

${ }^{50}$ Kropotkin, op. cit., Ref. 30.

${ }^{51}$ M. Mauss, The Gift: Forms and Functions of Exchange in Archaic Societies (London: Cohen \& West 1970).

${ }^{52}$ P. Linebaugh, The Magna Carta Manifesto: Liberties and commons for all (California: University of California Press 2008).

${ }^{53}$ Sargisson, op. cit., Ref. 56, p.22.

${ }^{54}$ Firth Utopian Politics, op. cit., Ref. 41, p, 74.

${ }^{55}$ L. Sargisson, 'Friends have all things in common: utopian property relations', The British Journal of Politics \& International Relations 12.1 (2010): pp. 22-36, p. 33.

${ }^{56}$ M.A. Bakunin, Bakunin: Statism and Anarchy, Ed. Marshall Shatz (Cambridge: Cambridge University Press, 1990), p. 146.

${ }^{57}$ Bakunin, ibid., p.13.

${ }^{58}$ Bakunin, ibid., p. 13, p. 146.

${ }^{59}$ Stirner, op. cit., Ref. 23.

${ }^{60}$ T. May, The Political Philosophy of Poststructuralist Anarchism (Penn State Press, 1994).

${ }^{61}$ S. Newman, From Bakunin to Lacan: Anti-authoritarianism and the Dislocation of Power (Lanham, MD: Lexington Books, 2001).

${ }^{62}$ S. Tormey, The End of Representative Politics (Hoboken, NJ: John Wiley \& Sons, 2015).

${ }^{63}$ J.S. Cohn, Anarchism and the Crisis of Representation: Hermeneutics, Aesthetics, Politics, (Cranbury: Associated University Press, 2006)

${ }^{64}$ Stirner, op. cit., Ref 23, p. 217; B. Black, Anarchy After Leftism, (Berkeley, CA: C.A.L. Press, 1997), p. 65.

${ }^{65}$ The Seeds for Change Collective, 'How To Make Decisions By Consensus', pp. 63-77 in The Trapese Collective (eds.), Do It Yourself: A Handbook for Changing our World, (London: Pluto Press, 2007).

${ }^{66}$ Seeds for Change, ibid., p. 75.

${ }^{67}$ Firth, Utopian Politics, op. cit., Ref. 41, p. 101. 
${ }^{68}$ Firth, ibid, p. 101-109. It is possible to use consensus in huge groups through the spokescouncil model (Seeds for Change, op. cit. Ref. 75: pp. 72-75) however I have not encountered this in intentional communities.

${ }^{69}$ D. Harvey, 'Listen, anarchist!', (2015) at http://davidharvey.org/2015/06/listen-anarchist-by-davidharvey/ accessed 7.02.2017.

${ }^{70}$ S. Springer, 'The limits to Marx: David Harvey and the condition of postfraternity.' (2015) available at:

https://www.academia.edu/12638612/The limits to Marx David Harvey and the condition of pos tfraternity, accessed 7.02.17.

${ }^{71}$ P-J. Proudhon, The Principle of Federation, Ed. Richard Vernon (Toronto: University of Toronto Press, 1979[1863]).

${ }^{72}$ C. Ward, 'The anarchist sociology of federalism', Freedom, (1992), Available at:

https://theanarchistlibrary.org/library/colin-ward-the-anarchist-sociology-of-federalism, accessed 11.02.2017.

73 The Red Sunshine Gang, Anti-Mass: Methods of organization for collectives (Montreal: Kersplebedeb, 1999 [c. 1970]), p. 151.

${ }^{74}$ L. Kohr, The Breakdown of Nations (London, Routledge, 1957).

${ }^{75}$ F. Schumacher, Small is Beautiful (London: Abacus 1974); K. Sale, Dwellers in the Land: The bioregional vision (University of Georgia Press, 1985).

${ }^{76}$ J. P. Clark, "Anarchy and the dialectic of utopia”, pp. 9-29 in Laurence Davis and Ruth Kinna (eds.), Anarchism and Utopianism (Manchester: Mancester University Press, 2009), p. 9

${ }^{77}$ Clark, ibid, p. 9.

${ }^{78}$ Moylan, op. cit., Ref. 17, p. 210

${ }^{79}$ Radical Routes, http://www.radicalroutes.org.uk/ , accessed 3.04.2017.

${ }^{80}$ Radical Routes, ibid.

${ }^{81}$ M. Bookchin, Social Anarchism or Lifestyle Anarchism: An unbridgable chasm, (Edinburgh and San Francisco: AK Press, 1995).

${ }^{82}$ Bookchin, ibid, p. $27-28$

${ }^{83}$ Bookchin, ibid, p. 34

${ }^{84}$ Bookchin, ibid., p. 7

${ }^{85}$ Bookchin, ibid., p. 52

${ }^{86}$ Bookchin, ibid., p. 58

${ }^{87}$ Black, op. cit., Ref. 74.

${ }^{88}$ Black, ibid., p. 54-55 
${ }^{89}$ Black, ibid., pp. 140-150; R. Day, Gramsci is Dead: Anarchist currents in the newest social movements, (London: Pluto Press, 2005); W. Landstreicher, 'From Politics to Life: Ridding anarchy of the leftist millstone', Killing King Abacus (2002, available at:

http://www.reocities.com/kk_abacus/ioaa/life.html, accessed 11.2.2017.

${ }^{90}$ A. Robinson, and S. Tormey, 'Utopias without Transcendence? Post-left Anarchy, Immediacy and Utopian Energy', pp. 156-75 in P. Hayden, and C. el-Ojeili (eds.), Globalization and Utopia: Critical essays (Hampshire, Palgrave Macmillan, 2009), p. 159.

${ }^{91}$ L. Sargisson, 'Politicising the quotidian', Environmental Politics, 10.2 (2001), pp. 68-89.

92 R.C. Schehr, Dynamic Utopia: Establishing intentional communities as a new social movement (Santa Barbara: Greenwood publishing group, 1977), p. 70.

${ }^{93}$ J. Aguilar, 'Food Choices and Voluntary Simplicity in Intentional Communities: What's Race and Class Got to Do with It?' Utopian Studies 26.1(2015), pp. 79-100.

${ }^{94}$ G. Kozeny, 'In Community, Intentionally', (2000), available at:

http://design.uoregon.edu/studio/coho/readings/kozeny-comm-dir-intro.pdf , accessed 11.02.2017.

${ }^{95}$ Kanter, op. cit., Ref. 52.

${ }^{96}$ Firth, Utopian Politics, op. cit., Ref. 41, p. 162.

${ }^{97}$ Mornington Grove Community, http://www.morningtongrovecommunity.org.uk/, accessed 4.04.2017.

${ }^{98}$ H. Bey, The Temporary Autonomous Zone, (Brooklyn, Autonomedia, 1991[1985]).

${ }^{99}$ Bey, ibid., p. 95

${ }^{100}$ Bey, ibid., p. 98

${ }^{101}$ S. Shukaitis, 'Nobody knows what an insurgent body can do: Questions for affective resistance', pp. 45-68 in Anarchism \& Sexuality: Ethics, Relationships and Power, Eds. Jamie Heckert and Richard Cleminson, (Abingdon: Routledge, 2011).

${ }^{102}$ Shukaitis, ibid., p. 51.

${ }^{103}$ J. Freeman, 'The Tyranny of Structurelessness', pp. 5-16 in Untying the Knot (London: Dark Star and Rebel Press, 1984[1972]), available from: http://www.bastardarchive.org/books/Freeman LevineUntying_the_knot-reading.pdf, accessed 4.04.2017, p. 6.

${ }^{104}$ Freeman, ibid., p. 10.

${ }^{105}$ Freeman, ibid., p. 11.

${ }^{106}$ Freeman, ibid., pp. 14-15.

${ }^{107}$ C. Levine, 'The Tyranny of Tyranny', pp. 17-32 in Untying the Knot, (London: Dark Star and Rebel Press 1984[1972]), available from: http://www.bastardarchive.org/books/Freeman_LevineUntying_the_knot-reading.pdf, accessed 11.02.2017, p. 17.

${ }^{108}$ Levine, ibid., p. 17. 
${ }^{109}$ Firth, Utopian Politics, op. cit., Ref. 42, pp. 109-110.

${ }^{110}$ J. McQuinn, 'A Review of The Tyranny of Structurelessness: An organizationalist repudiation of anarchism', Anarchy: A Journal of Desire Armed 54 (2002), available at:

https://theanarchistlibrary.org/library/jason-mcquinn-a-review-of-the-tyranny-of-structurelessness-anorganizationalist-repudiation-of, accessed 11.02.2017.

${ }^{111}$ McQuinn, ibid.

${ }^{112}$ Freeman, 1972, op. cit., Ref. 114, cited in McQuinn, op. cit. Ref. 121.

${ }^{113}$ B. Anderson, Imagined communities: Reflections on the origin and spread of nationalism, (London: Verso Books, 2006). 